\title{
Incorporation of Bromelain into Dermatological Bases: Accelerated Stability Studies
}

\author{
Iara Rocha Antunes Pereira Bresolin ${ }^{1}$, Igor Tadeu Lazzarotto Bresolin ${ }^{2 *}$, Priscila Gava Mazzola ${ }^{3}$ and Elias Basile \\ Tambourgi $^{1}$ \\ 1. School of Chemical Engineering, University of Campinas (Unicamp), Campinas 13083-970, Brazil \\ 2. Institute of Environmental, Chemical and Pharmaceutical Sciences, Federal University of São Paulo (Unifesp), Diadema \\ 09972-270, Brazil \\ 3. Faculty of Medical Sciences, University of Campinas (Unicamp), Campinas 13083-881, Brazil
}

Received: January 11, 2014 / Accepted: January 28, 2014 / Published: March 25, 2014.

\begin{abstract}
This work aimed the incorporation of the enzyme bromelain from pineapple peel into dermatological bases for potential therapeutic application. The enzyme was incorporated into Lanette cream and lotion, as well as Carbopol gel and Chemyunion ${ }^{\circledR}$ cream and lotion, at a concentration of $0.5 \%(\mathrm{w} / \mathrm{w})$. These bases were subjected to centrifugation test and accelerated stability test during 90 days at $25^{\circ} \mathrm{C}$ (with and without sunlight), $37^{\circ} \mathrm{C}$ and $4{ }^{\circ} \mathrm{C}$, in order to evaluate bromelain stability in dermatological bases. Total protein content and enzymatic activity were measured. The bases were stable as its organoleptic characteristics (appearance, color, smell and sensitivity to touch) only when kept at $4{ }^{\circ} \mathrm{C}$ with activity remaining $95.5 \%, 84,9 \%, 77.7 \%, 73.8 \%$ and $72.3 \%$, after 90 days of testing in Carbopol gel, Lanette and Chemyunion ${ }^{\circledR}$ cream, and Lanette and Chemyunion ${ }^{\circledR}$ lotion, respectively. Based on the results, it was possible to incorporate bromelain into dermatological bases, and the activity was well preserved when these bases were kept in refrigerator at $4{ }^{\circ} \mathrm{C}$.
\end{abstract}

Key words: Emulsions, stability, bromelain, therapeutic applications, enzymatic activity.

\section{Introduction}

Pineapple is considered the third most important fruit in the world with a projected production of 18.7 million tons for 2014 [1]. In addition to being consumed in natura, pineapple is also submitted to industrial processes, generating wastes such as peel, stem and centrifuged solids (from juice production), corresponding to $35 \%-40 \%$ of the pineapple mass [2]. Since the pineapple industry by-products have a low commercial appeal, they are directly returned to the fields as processed soil amendment in order to obtain bran used for cattle feed [2]. However, these wastes are rich in bromelain enzyme that could be recovered and purified in order to generate a product higher

*Corresponding author: Igor Tadeu Lazzarotto Bresolin, Associate Professor/Ph.D., research field: protein purification. E-mail: igor.bresolin@gmail.com. aggregate value.

Bromelain is a proteolytic enzyme found in vegetable tissues like peel, stem, fruit and leaves of the Bromeliaceae family, including pineapple (Ananas comosus). The enzyme found in pineapple stem (EC 3.4.22.32) is sulphydrylic, and the sulphydryl group is essential to the proteolytic activity [2, 3]. The one found in pineapple fruit (EC 3.4.22.33) is an acid protein, and its isoelectric point (pI) is 4.6, determined by isoelectric focusing (IEF). Irreversible conformational changes occur at $\mathrm{pH}$ values higher than 10.3 [3].

Due to its proteolytic activity, bromelain has been extensively used as active for therapeutic applications in several animal models [4-6]. A wide range of therapeutic benefits have been attributed to bromelain due to its action as therapeutic agent in inflammation, autoimmunity and allergy, as well as the reversible 
inhibition of platelet aggregation, bronchitis relief, improved recovery after surgical traumas, and enhanced absorption of drugs, particularly antibiotics [7-10]. Enzymatic debridement of necrotic tissues from ulcers, burn wounds and frostbite eschar, as well as antiproliferative and antimetastatic effects on tumor models have been also presented in Refs. [4, 6, 11].

The incorporation of an active into a dermatological base aims topical administration, allowing local action. However, the property to permeate the skin depends on the active ability of liberation from the formulation, and the diffusion to its site of action. The drugs applied to the skin for local effect agents include antiseptics, antifungals and anti-inflammatories, as well as skin emollients for protection [12].

Dermatological bases can be defined as semi-solid preparations containing one or more medicinal or cosmetic agents for external use in different parts of the human body for cleaning, perfuming, correcting odors and protection [13-16].

Different factors can affect the development of cosmetic products containing active ingredients or not. In order to ensure the quality of the final product, factors such as the composition, physicochemical studies on the efficacy and safety and possible incompatibilities in the formulation should be evaluated and monitored [14, 17, 18]. After selecting the formulations, it is crucial to do stability tests at different conditions of temperature, light and humidity [13].

The incorporation of plant extracts into cosmetic bases requires careful studies and should consider factors such as system compatibility, considering the conditions of extract storage, choice of solvents used in their dispersion, formulation temperature during active incorporation and packaging material or final packaging. The formulation stability should be ensured during the entire period of validity, maintaining its characteristics according to specifications previously established [19, 20].

This work aimed to incorporate and study the accelerated stability of bromelain enzyme from pineapple peel into dermatological bases in four different conditions: $25^{\circ} \mathrm{C}$ (with and without sunlight), $37{ }^{\circ} \mathrm{C}$ and $4{ }^{\circ} \mathrm{C}$. The following dermatological bases were used: Lanette cream and lotion, Carbopol gel and Chemyunion ${ }^{\circledR}$ cream and lotion. Comparative studies were performed in dermatological bases containing the purified enzyme and the enzyme commercially available.

\section{Materials and Methods}

\subsection{Plant Material}

The pineapple (Ananas comosus) peel, from "pearl" variety, used in this study, was acquired in a local market. They were washed and used for bromelain extraction and purification in accordance with Ref. [21] methodology.

\subsection{Chemicals}

A commercial stem bromelain (EC 3.4.22.32) lyophilized powder was purchased from Sigma (USA) and used as standard in the experiments performed. Crystalline BSA (bovine serum albumin) and azocasein were acquired from Sigma (USA). TCA (trichloroacetic acid) was acquired from Synth (Brazil). O-phosphoric acid was acquired from Ecibra (Brazil). Coomassie blue and carbopol 940 were acquired from Vetec (Brasil). Cetearyl alcohol, polysorbate 60, ceteareth-20, methylparaben, ethylparaben, propilparaben, butylparaben, phenoxyethanol, EDTA, propyleneglycol, lanolin alcohol and mineral oil were acquired from Chemyunion (Brazil). Imidazolidinyl urea and triethanolamine were acquired from Mix das Essências (Brazil). Cetostearyl alcohol and decyl oleate were acquired from Casa das essências (Brazil). The water used for preparing the bases was ultrapure (Milli-Q System, Millipore, USA). All other chemicals were of analytical reagent grade.

\subsection{Preparation of Dermatological Bases}

The following formulations were evaluated: 
anionic - Lanette cream and lotion and Carbopol gel; nonionic —Chemyunion ${ }^{\circledR}$ cream and lotion. Purified bromelain $0.5 \%(\mathrm{w} / \mathrm{w})$ and commercial bromelain $0.5 \%(\mathrm{w} / \mathrm{w})$ (positive control) were incorporated separately into all bases, and these same formulations were analyzed without bromelain addition (negative control). All bases were stored in glass bottles and capped. To measure enzymatic activity, total protein concentration, and $\mathrm{pH}$ was necessary to dilute the sample 10 times with water.

\subsubsection{Lanette Cream}

Lanette cream was prepared by mixing the oil phase (cetostearyl alcohol 15\% (w/w), decyl oleate 3\% (w/w), mineral oil 2\% (w/w) and propilparaben $0.05 \%$ $(\mathrm{w} / \mathrm{w})$ ); and the aqueous phase (methylparaben $0.15 \%$ (w/w), propylene glycol 5\% (w/w) and Milli-Q water). Both phases were warmed to $70{ }^{\circ} \mathrm{C}$ separately, and then the aqueous phase was slowly added into the oil phase under constant agitation. The agitation was performed until the emulsion reached room temperature.

\subsubsection{Lanette Lotion}

Lanette lotion was prepared by mixing the oil phase (cetostearyl alcohol 6\% (w/w), decyl oleate 5\% (w/w), mineral oil 5\% (w/w) and propilparaben $0.1 \%(\mathrm{w} / \mathrm{w})$ ); and the aqueous phase (methylparaben $0.15 \%(\mathrm{w} / \mathrm{w})$, glycerin 5\% (w/w) and Milli-Q water). Both phases were warmed to $70{ }^{\circ} \mathrm{C}$ separately, and then the aqueous phase was slowly added into the oil phase under constant agitation. The agitation was performed until the emulsion reached room temperature.

\subsubsection{Carbopol Gel}

Carbopol gel was prepared by mixing carbopol 940 $1 \%(\mathrm{w} / \mathrm{w})$ and Milli-Q water in a becker and methylparaben $0.15 \%(\mathrm{w} / \mathrm{w})$, imidazolidinyl urea $0.3 \%$ and propylene glycol $5 \%(\mathrm{w} / \mathrm{w})$ in another backer. Both phases were mixed. The volume of water was completed. Drops of triethanolamine were added to adjust the $\mathrm{pH}$ value to 6 .

\subsubsection{Chemyunion ${ }^{\circledR}$ Cream}

Chemyunion ${ }^{\circledR}$ cream was prepared by mixing the oil phase ((cetearyl alcohol and polysorbate 60) 10\% $(\mathrm{w} / \mathrm{w})$, cetostearyl alcohol 1.5\% (w/w), mineral oil 2\% $(\mathrm{w} / \mathrm{w})$, lanolin alcohol $1.5 \% \quad(\mathrm{w} / \mathrm{w})$ and (methylparaben, ethylparaben, propilparaben, butylparaben and phenoxyethanol) $0.5 \%(\mathrm{w} / \mathrm{w})$ ); and the aqueous phase (EDTA $0.10 \%(\mathrm{w} / \mathrm{w})$ and Milli-Q water). Both phases were warmed to $80{ }^{\circ} \mathrm{C}$ separately, and then the aqueous phase was slowly added into the oil phase under constant agitation. The agitation was performed until the emulsion reached room temperature.

\subsubsection{Chemyunion ${ }^{\circledR}$ Lotion}

Chemyunion ${ }^{\circledR}$ lotion was prepared by mixing the oil phase ((Cetearyl alcohol, ceteareth-20) 4\% (w/w), cetostearyl alcohol $2 \%(\mathrm{w} / \mathrm{w})$, mineral oil $2 \%(\mathrm{w} / \mathrm{w})$, lanolin alcohol 2\% (w/w) and (methylparaben, ethylparaben, propilparaben, butylparaben and phenoxyethanol) $0.5 \%(\mathrm{w} / \mathrm{w})$ ); and the aqueous phase (EDTA $0.10 \%(\mathrm{w} / \mathrm{w})$, propylene glycol 5\% (w/w) and Milli-Q water). Both phases were warmed to $80{ }^{\circ} \mathrm{C}$ separately, and then the aqueous phase was slowly added into the oil phase under constant agitation. The agitation was performed until the emulsion reached room temperature.

\subsection{Stability Study of Dermatological Bases}

Stability study was performed in accordance with the standards of Brazilian Health Surveillance Agency [13].

\subsubsection{Centrifugation Test}

Centrifugation test was made with all bases, using $15 \mathrm{~mL}$ Falcon ${ }^{\circledR}$ tubes at 3,000× $\mathrm{g}$ for $30 \mathrm{~min}$.

2.4.2 Accelerated Stability (Normal or Exploratory Stability)

Accelerated stability test was performed with all bases that were approved in centrifugation test. Test was conducted at $25{ }^{\circ} \mathrm{C}$ (with and without sunlight), $37{ }^{\circ} \mathrm{C}$ and $4{ }^{\circ} \mathrm{C}$. The following parameters were evaluated: organoleptic characteristics (appearance, color, smell and sensitivity to touch), $\mathrm{pH}$, total protein and enzymatic activity. The samples were analyzed at times: 0, 1, 7, 15, 30, 60 and 90 days. 


\subsection{Analytical Methods}

\subsubsection{Bromelain Activity}

Protease activity was assayed using the azocasein method by monitoring the rate of release of TCA soluble-azo-coupled peptides from azocasein at 440 $\mathrm{nm}$ [22]. The reaction mixture contained $0.2 \mathrm{~mL} 2 \%$ azocasein (w/v) and $0.2 \mathrm{~mL}$ enzyme appropriately diluted in $25 \mathrm{mmol} \cdot \mathrm{L}^{-1}$ potassium phosphate buffer at $\mathrm{pH}$ 7.0. The reaction was started by the addition of enzyme aliquot and azocasein solution. After incubating it for $10 \mathrm{~min}$ at $37^{\circ} \mathrm{C}$, the reaction was arrested by adding $1.2 \mathrm{~mL}$ of $5 \%$ TCA (w/v). The mixture was centrifuged at $6000 \times \mathrm{g}$ for $10 \mathrm{~min}$ to collect the supernatant containing TCA-soluble azo-coupled peptides. Supernatant absorbance at 440 nm was measured against the corresponding blank run, in the absence of enzyme. One unit of protease activity is defined as the amount of enzyme required to produce an absorbance change of 1.0 in a $1 \mathrm{~cm}$ cuvette, under assay conditions.

\subsubsection{Protein Determination}

Total protein content was analyzed by Coomassie blue dye technique, according to the procedure described by the Bradford method, using BSA as a reference protein [23]. The intensity of the color was
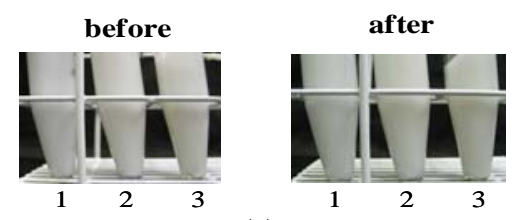

(a)
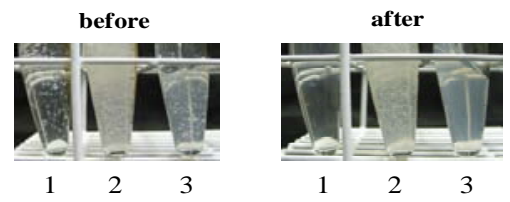

(c)

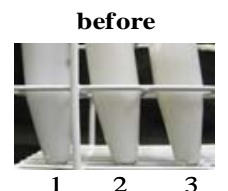

measured at $595 \mathrm{~nm}$.

\section{Results and Discussion}

Bromelain is an enzyme with therapeutic potential of cicatrization. After the process of purification, the enzyme was incorporated into different dermatological bases in order to study its stability in these bases under different conditions of storage and compare the behavior of the purified enzyme with the enzyme commercially available. The bases presented anionic (Lanette cream and lotion and Carbopol gel) and nonionic (Chemyunion ${ }^{\circledR}$ cream and lotion) characteristics. Centrifuge and accelerated stability tests were conducted for all studied bases. Total protein, $\mathrm{pH}$, enzymatic activity and organoleptic characteristics (appearance, color, smell and sensitivity to touch) were evaluated during 90 days.

\subsection{Centrifugation Test}

Aiming to observe possible physical instabilities in dermatological bases, centrifugation was the first test made. In this test, a known amount of the dermatological base (approximately $10 \mathrm{~g}$ ) with and without bromelain was subjected to centrifugation at $3,000 \times \mathrm{g}$ for $30 \mathrm{~min}$. Physical instability was not observed in formulations (Fig. 1).
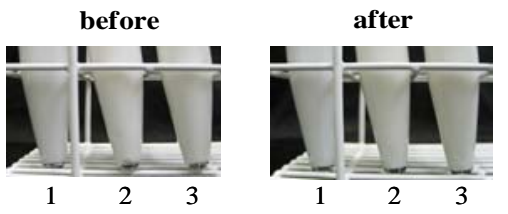

(b)
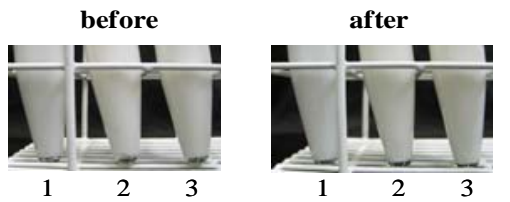

(d)

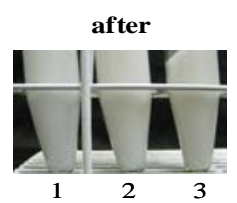

(e)

Fig. 1 Centrifugation test: (a) Lanette cream, (b) Lanette lotion, (c) Carbopol gel, (d) Chemyunion cream, (e) Chemyunion lotion. (1) Base without bromelain, (2) base with commercial bromelain and (3) base with purified bromelain in the laboratory. 


\subsection{Accelerated Stability Test}

Aiming to estimate the lifetime and shelf life of formulations, the accelerated stability test was carried out for all bases, analyzing organoleptic characteristics, $\mathrm{pH}$, total protein and enzymatic activity under four different conditions: $25{ }^{\circ} \mathrm{C}$ with indirect sunlight, $25^{\circ} \mathrm{C}$ without light incidence, $37^{\circ} \mathrm{C}$ and $4{ }^{\circ} \mathrm{C}$. These conditions are designed to increase the rate of chemical degradation and physical modification of a substance and/or changes in characteristics of pharmaceutical forms by using forced storage conditions [13]. Like any predictive procedure, the results of stability tests are not absolute, but have high probability of success, which tends to increase if the test conditions are close to those of market and also when test duration is longer [13].

Organoleptic characteristics (appearance, color, smell and sensitivity to touch) have not changed in
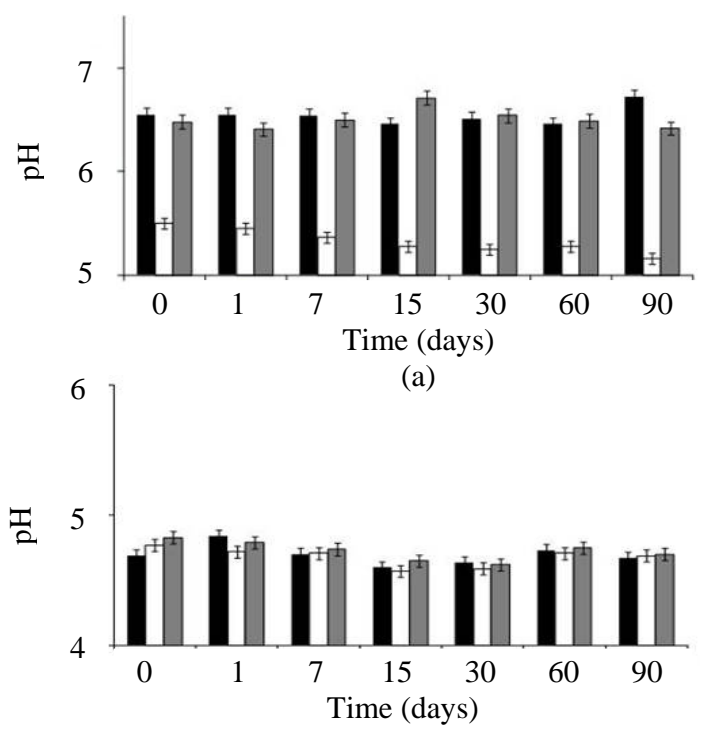

(c) bases at $4{ }^{\circ} \mathrm{C}$. The color and smell have changed with increasing the temperature of formulations containing commercial bromelain and purified bromelain. At $25{ }^{\circ} \mathrm{C}$ (with and without sunlight), these characteristics have became slightly modified from the 60th test day and, at $37^{\circ} \mathrm{C}$, these changes were initiated from the 7 th day, making it highly modified at the end of the test.

At low temperatures, it is possible to accelerate physical changes, turbidity, precipitation and crystallization. Problems generated due to low temperatures may result also from nonconformities in the manufacturing process, storage, or product transport [13]. According to Brazilian Health Surveillance Agency Recommendations (2004), the temperature limit most used during product development are in the refrigerator $\left(5^{\circ} \mathrm{C} \pm 2{ }^{\circ} \mathrm{C}\right)$ and freezer $\left(-5{ }^{\circ} \mathrm{C} \pm 2{ }^{\circ} \mathrm{C}\right.$ or $\left.-10{ }^{\circ} \mathrm{C} \pm 2{ }^{\circ} \mathrm{C}\right)$ [13]. The $\mathrm{pH}$ profiles and variation of the enzymatic activity of
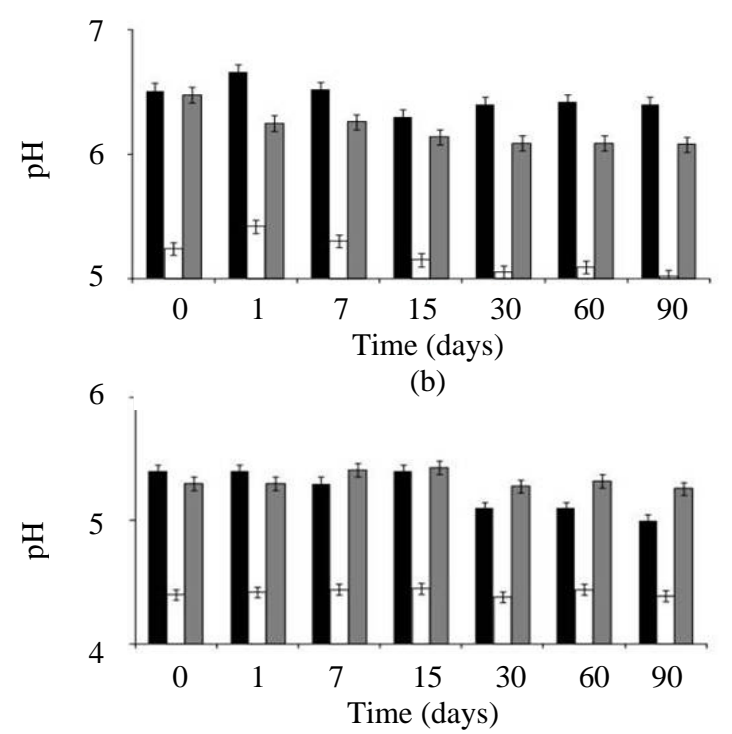

(d)

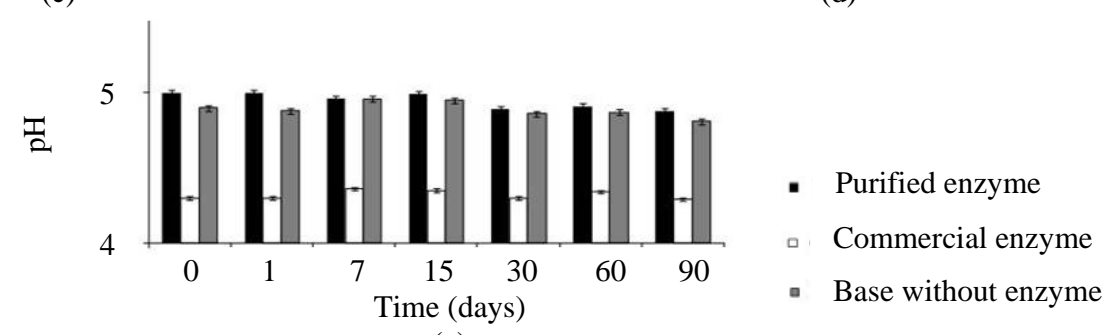

(e)

Fig. 2 pH profile at $4{ }^{\circ} \mathrm{C}$ : (a) Lanette cream; (b) Lanette lotion; (c) Carbopol gel; (d) Chemyunion ${ }^{\circledR}$ cream and (e) Chemyunion ${ }^{\circledR}$ lotion. Error bars represent confidence interval of $95 \%$ in the obtained values. 


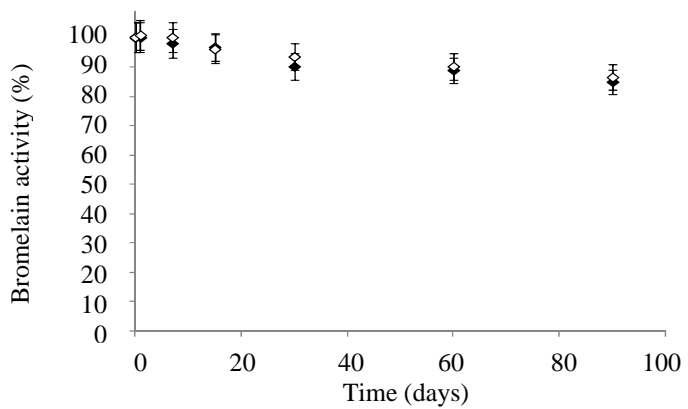

(a)

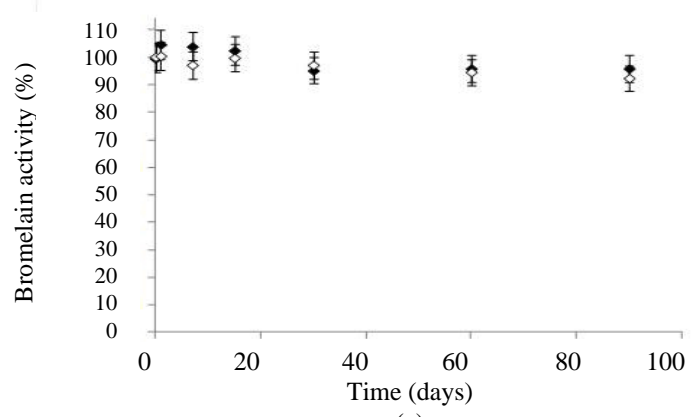

(c)

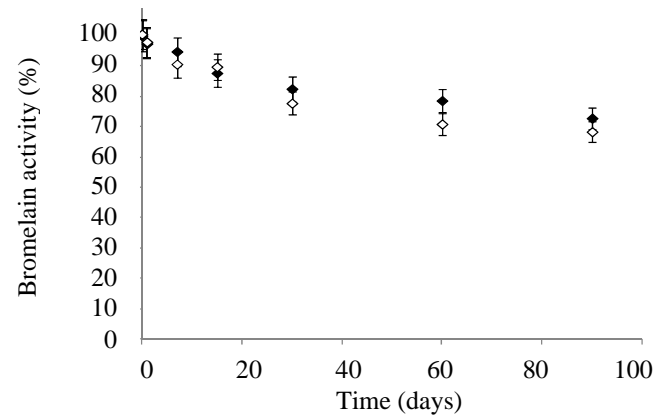

(e)

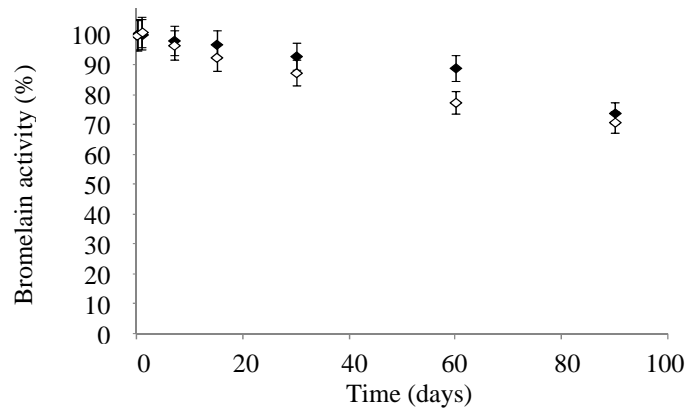

(b)

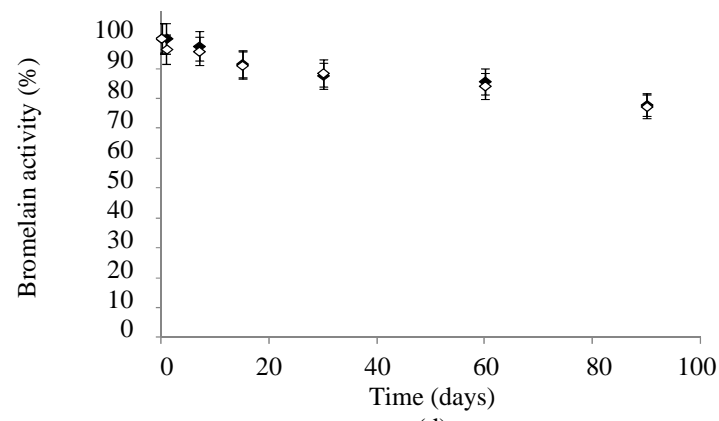

(d)

- Purified enzyme

口 Commercial enzyme

Fig. 3 Profile of enzymatic activity of bromelain at $4{ }^{\circ} \mathrm{C}$ : (a) Lanette cream, (b) Lanette lotion, (c) Carbopol gel, (d) Chemyunion ${ }^{\circledR}$ cream, (e) Chemyunion ${ }^{\circledR}$ lotion. Error bars represent confidence interval of $95 \%$ in the obtained values.

bromelain at $4{ }^{\circ} \mathrm{C}$ are shown in Figs. 2 and 3 , respectively.

According to the results shown in Table 1, temperature is of paramount relevance in the stability of formulations containing bromelain because high temperature $\left(37^{\circ} \mathrm{C}\right)$ caused enzyme degradation due to the virtual loss of all of their activity during the 90-day test (data not shown). All studied bases presented the same degradation, either with purified or commercial enzyme. In turn, when the bases were maintained at low temperature $\left(4^{\circ} \mathrm{C}\right)$, it was observed the lowest activity loss throughout the test (Fig. 3 and Table 1). At $25{ }^{\circ} \mathrm{C}$, enzymatic activity lost was intermediate to the values obtained at $37^{\circ} \mathrm{C}$ and $4{ }^{\circ} \mathrm{C}$.
The incidence or absence of light was not significant in relation to loss of enzymatic activity (Table 1 ).

Lanette cream and lotion and Carbopol gel formulations are anionic (negatively charged). For this reason, the incorporation of products with a positive charge tends to destabilize the formulation. Thus, the incorporation of negatively charged molecules can be performed in these formulations. According to Ref. [2], the isoelectric point (pI) of bromelain is 4.6; then, under the $\mathrm{pH}$ condition of anionic studied bases $(\mathrm{pH}$ 6.5 for Lanette cream and lotion and $\mathrm{pH} 5.0$ for Carbopol gel), bromelain is negatively charged, therefore, being compatible to be incorporated into anionic formulations. 
Table 1 Remaining activities of bromelain in dermatological bases after 90 days of stability test.

\begin{tabular}{lllll}
\hline Base & $25{ }^{\circ} \mathrm{C}$ with sunlight $(\%)$ & $25^{\circ} \mathrm{C}_{\text {without sunlight }}(\%)$ & $37^{\circ} \mathrm{C}(\%)$ & $4{ }^{\circ} \mathrm{C}(\%)$ \\
\hline Lanette cream $^{1}$ & 41.5 & 41.0 & 5.0 & 87.2 \\
Lanette cream $^{2}$ & 42.7 & 42.4 & 9.6 & 84.9 \\
Lanette lotion $^{1}$ & 38.5 & 39.5 & 0.0 & 71.8 \\
Lanette lotion $^{2}$ & 37.5 & 38.5 & 0.9 & 73.8 \\
Carbopol gel $^{1}$ & 51.2 & 51.3 & 2.5 & 92.3 \\
Carbopol gel $^{2}$ & 50.4 & 54.0 & 8.9 & 95.5 \\
Chemyunion $^{\circledR}$ cream $^{1}$ & 50.0 & 51.2 & 2.5 & 77.5 \\
Chemyunion $^{\circledR}$ cream $^{2}$ & 51.2 & 57.0 & 4.6 & 77.7 \\
Chemyunion $^{\circledR}$ lotion $^{1}$ & 44.7 & 45.9 & 0.0 & 67.6 \\
Chemyunion $^{\circledR}$ lotion $^{2}$ & 46.8 & 48.7 & 0.0 & 72.3 \\
\hline
\end{tabular}

${ }^{1}$ Base with commercial bromelain;

${ }^{2}$ Base with purified bromelain.

The Carbopol gel formulation showed the best results in relation to enzyme stability (Table 1). It is believed that this result occurred due to the Carbopol gel base being more acidic, since the pineapple is an acidic fruit, thus keeping the enzyme active longer and closer to a natural $\mathrm{pH}$.

The $\mathrm{pH}$ values did not vary significantly throughout the study for studied bases under all storage conditions, but showed a slight tendency to decrease (Fig. 2). Commercial formulations containing bromelain had lower $\mathrm{pH}$ values because the commercial enzyme was lyophilized in acid $\mathrm{pH}$.

Creams showed better results of enzyme stability than lotions (Table 1) because lotions are richer in water and bromelain self degradates in aqueous media.

The enzymatic stability profiles in purified bromelain and commercially available enzyme were very similar, as it can be seen in Fig. 3.

Further reductions in enzyme activity occurred in the tests at $37{ }^{\circ} \mathrm{C}$, which is precisely the optimum temperature of bromelain [24, 25]. It is believed that this activity loss has occurred due to self-degradation (autolysis, or autodigestion) of bromelain because it is under the condition of maximum activity.

Miura studied the effect of technical adjuvant disodium EDTA, cysteine hydrochloride and propylene glycol on increased proteolytic activity of papain in Carbopol gels [26]. The author performed accelerated stability test in bases containing papain at temperatures of 5,26 and $45{ }^{\circ} \mathrm{C}$ for 60 days and concluded that there was good physical stability, but there was a loss of proteolytic activity values $\left(5{ }^{\circ} \mathrm{C}-30 \%, 26{ }^{\circ} \mathrm{C}-32 \%\right.$ and $\left.45{ }^{\circ} \mathrm{C}-39 \%\right)$. Using technical adjuvants, the proteolytic activity was considerably greater in the beginning, but there was not maintenance of this activity over time of accelerated stability study. Baby and coworkers performed accelerated stability test in oil/water emulsions containing extract of Trichilia catigua Adr. Juss and Ptychopetalum olacoides Bentham during 90 days [27]. The results showed acceptable stability at $24{ }^{\circ} \mathrm{C}$ with and without sunlight, with loss of approximately $10 \%$ of total flavonoid and, at $5{ }^{\circ} \mathrm{C}$, there was a loss of approximately $5 \%$ of total flavonoid. At $40{ }^{\circ} \mathrm{C}$, there was accelerated degradation with loss of approximately $39 \%$ of total flavonoid.

\section{Conclusions}

It was possible to incorporate bromelain into Carbopol gel, Lanette and Chemyunion ${ }^{\circledR}$ cream and lotion. When the bases were kept at $4{ }^{\circ} \mathrm{C}$, after 90 days of testing, bromelain remained more stable in relation to organoleptic characteristics with activity remaining of $95.5 \%, 84.9 \%, 77.7 \%, 73.8 \%$ and $72.3 \%$, in Carbopol gel, Lanette and Chemyunion ${ }^{\circledR}$ cream, and Lanette and Chemyunion ${ }^{\circledR}$ lotion, respectively. The preservation of enzymatic activity was better in Carbopol gel. 


\section{Acknowledgments}

The authors gratefully acknowledge the scholarship received from $\mathrm{CNPq}$ and the financial support from CAPES/PROEX (Brazil).

\section{References}

[1] Food and Agriculture Organization of the United Nations. http://www.fao.org/es/esc/common/ecg/218/en/Sit_web_ e.pdf (accessed July 04, 2012).

[2] Bartholomew, D. P.; Paull, R. E.; Rohrbach, K. G. The Pineapple: Botany, Production and Uses; CABI Publishing: Wallingford-UK, 2003.

[3] Hale, L. P.; Greer, P. K.; Trinh, C. T.; James, C. L. Proteinase Activity and Stability of Natural Bromelain Preparations. Int. Immunopharmacol. 2005, 5, 783-793.

[4] Ahle, N. W.; Hamlet, M. P. Enzymatic Frostbite Eschar Debridement by Bromelain. Ann. Emerg. Med. 1987, 16, 1063-1065.

[5] Bahde, R.; Palmes, D.; Minin, E.; Stratmann, U.; Diller, R.; Haier, J.; et al. Bromelain Ameliorates Hepatic Microcirculation after Warm Ischemia. J. Surg. Res. 2007, 139, 88-96.

[6] Bhui, K.; Prasad, S.; George, J.; Shukla, Y. Bromelain Inhibits COX-2 Expression by Blocking the Activation of MAPK Regulated NF-Kappa B Against Skin Tumor-Initiation Triggering Mitochondrial Death Pathway. Cancer Lett. 2009, 282, 167-176.

[7] Kelly, G. S. Bromelain: A Literature Review and Discussion of Its Therapeutic Applications. Altern. Med. Rev. 1996, 1, 243-257.

[8] Murakawa, T.; Yamagata, H.; Tsuruta, H.; Aizono, Y. Cloning of Cold-Active Alkaline Phosphatase Gene of a Psychrophile, Shewanella sp., and Expression of the Recombinant Enzyme. Biosci. Biotechnol. Biochem. 2002, 66, 754-761.

[9] Roep, B. O.; Engel, N. K.; Halteren, A. G.; Duinkerken, G.; Martin, S. Modulation of Autoimmunity to Beta-Cell Antigens by Proteases. Diabetologia. 2002, 45, 686-692.

[10] Secor, E. R.; Singh, A.; Guernsey, L. A.; McNamara, J. T.; Zhan, L.; Maulik, N.; et al. Bromelain Treatment Reduces CD25 Expression on Activated CD4+ T Cells in Vitro. Int. Immunopharmacol. 2009, 9, 340-346.

[11] Napper, A. D.; Bennett, S. P.; Borowski, M.; Holdridge, M. B.; Leonard, M. J.; Rogers, E. E.; et al. Purification and Characterization of Multiple Forms of the Pineapple-Stem-Derived Cysteine Proteinases Ananain and Comosain. Biochem. J. 1994, 301, 727-735.

[12] Auton, M. E. Design of Pharmaceutical Dosage Forms. Editora Artmed: Porto Alegre-Brazil; p 2005.

[13] Brazilian Health Surveillance Agency. Guide for Stability of Cosmetic Products. Thematic Series; Ministry of Health: Brasília-Brazil, 2004; Vol. 1.

[14] Gorouhi, F.; Maibach, H. I. Role of Topical Peptides in Preventing or Treating Aged Skin. Int. J. Cosmetic Sci. 2009, 31, 327-345.

[15] Kanlayavattanakul, M.; Lourith, N. Lipopeptides in Cosmetics. Int. J. Cosmetic Sci. 2010, 32, 1-8.

[16] Kanlayavattanakul, M.; Lourith, N. Body Malodours and Their Topical Treatment Agents. Int. J. Cosmetic Sci. 2011, 33, 298-311.

[17] Simmons, J. V. Cosmetics: Formulation, Preparation and Application; Madrid Vicente: Madrid, 2000.

[18] Schueller, R.; Romanowsky, P. Introduction to Cosmetic Chemistry; Tecnopress: São Paulo, 2002.

[19] Banov, D. Development and Evaluation of the Stability of Cosmetic Formulations Containing Dry Extract of Ginkgo Biloba L. Master Thesis, University of São Paulo, 2002.

[20] Baby, A. R. Development and Evaluation of the Stability of Cosmetic Formulations Containing Anticelulitic Commercial Extract of Trichilia catiguá Adr. Juss and Ptychopetalum olacoides Bentham, Standardized in Total Flavonoids. Master Thesis, University of São Paulo, 2005.

[21] Bresolin, I. R. A. P.; Bresolin, I. T. L.; Silveira, E.; Tambourgi, E. B.; Mazzola, P. G. Isolation and Purification of Bromelain from Waste Peel of Pineapple for Therapeutic Application. Braz. Arch. Biol. Techn. 2013, 56, 971-979.

[22] Sarath, G.; De La Motte, R. S.; Wagner, F. W. Protease Assay Methods. In Proteolytic Enzymes: A Practical Approach; Beynon, R. J., Bonde, J. S., Eds.; Oxford University Press: Oxford, 1989; pp 25-54.

[23] Bradford, M. M. A Rapid and Sensitive Method for the Quantitation of Microgram Quantities of Protein Utilizing the Principle of Protein-Dye Binding. Anal. Biochem. 1976, 72, 248-254.

[24] Rasheedi, S.; Haq, S. K.; Khan, R. H. Guanidine Hydrochloride Denaturation of Glycosylated and Deglycosylated Stem Bromelain. Biochemistry-US. 2003, 68, 1097-1100.

[25] Khan, R. H.; Rasheedi, S.; Haq, S. K. Effect of pH, Temperature and Alcohols on the Stability of Glycosylated and Deglycosylated Stem Bromelain Enzymes. J. Biosciences 2003, 28, 709-714.

[26] Miura, D. Y. Pharmaceutics Development and Stability Study of Papain Gels for the Wounds Treatment. Master Thesis, Fluminense Federal University, 2012.

[27] Baby, A. R.; Migliato, K. F.; Maciel, C. P. M.; Zague, V.; Pinto, C. A. S. O.; Salgado, H. R. N.; et al. Accelerated Chemical Stability Data of $\mathrm{O} / \mathrm{W}$ Fluid Emulsions Containing the Extract of Trichilia catigua Adr. Juss (and) Ptychopetalum olacoides Bentham. Rev. Bras. Cienc. Farm. 2007, 43, 405-412. 